\title{
A BRIEF ANALYSIS ON PREVENTIVE MEASURES INVOLVING DEPRIVATION OF LIBERTY Denisa BARBU
}

\author{
"Valahia" University, Târgovişte, Romania, \\ denisa.barbu77@yahoo.com
}

\begin{abstract}
Preventive measures are divided by the legislator in 2 categories: imprisonment (detention, house arrest, preventive arrest) and restrictive of rights (judicial review and judicial control on surety). An absolute novelty is the introduction of house arrest. There is some controversy concerning the conditions which must be fulfilled in order to be disposed by the judge of rights and freedoms, the judge of preliminary Chamber or Panel of judges either the house arrest or the measure of preventive arrest.

Whereas the establishment of preventive measures involves undermining the individual freedom, the national and the European laws have created a series of legal guarantees to prevent arbitrariness or abuse in making or extend/maintain them. There are also a number of provisions of a general nature, applicable to all preventive measures, namely, termination, revocation or replacement thereof. For all measures involving deprivation of liberty, general conditions must be fulfilled, stipulated by article 202, of the Code of Criminal Procedure, but for house arrest and detention in addition to the General conditions, special conditions should be fulfilled foreseen by article 223 of the Code of Criminal Procedure, conditions which must be cumulatively met.

Not fulfilling the cumulative criteria laid down in national and European norms cannot be replaced by other considerations of the judge.
\end{abstract}

Keywords: house arrest, detention, preventive arrest, termination, contestation

\section{Introduction}

Preventive measures can be arranged for the purpose of the criminal process [1], the legislator conditioning taking such preventive measures in at least one of the cases provided for in article 202 of the Criminal Procedure Code, on the one hand, and, on the other hand, in order to underline, thus, the preventive and retributive nature [2] (penalties, characteristic to criminal sanctions) that such measures must take during the criminal process.

Judicial bodies are required to choose a preventive measure proportional and sufficient to achieve the goal envisaged by article 202 paragraph 1 of the Criminal
Procedure Code, in light of the danger clearly determined and found to be preencountered or removed.

The choice of the preventive measure to be taken is done taking into account its purpose, the seriousness of the offence, the manner and the circumstances of instigating the offence and the person to whom it has the measure of prevention.From the analysis of the provisions of article 202, paragraphs 1-3 and the dispositions of the article 223, it follows that the preventive measure shall be taken under the conditions in which the General conditions are carried out and if any event referred to in article 223 is also carried out. 
The preventive / pre-trial arrest is the hardest of the preventive measures having regard to the exceptional nature,normally, being based on actual evidence, not on simple cues, which were insufficient.Furthermore, it should be also stressed the specific measure for the pretrial detention, the need for taking this measure, because there's another preventive measure, i.e. home arrest, which may be ordered by the judge of rights and freedoms, the Preliminary Chamber judge or by the Court, for the same reasons as the measure of pre-trial detention.

For taking the preventive measures, a number of General conditions must be carried out [3], the conditions which must be fulfilled cumulatively (there is evidence or reasonable indications showing a reasonable suspicion that a person has committed an offence, preventive measure should be necessary in order to ensure the proper conduct of the criminal trial of the suspect or defendant, the prevention from prosecution or trial, or preventing the recurrence of another offence, the preventive measure must be proportionate to the gravity of the accusation brought to the person, which it is taken and necessary for achieving the aim pursued through its arrangement [3, p. 630]), and furthermore to be performed alternatively and either referred to in article 223 The Criminal Procedure Code. [4]

According to the jurisprudence of the ECHR, the legality is one of the fundamental principles on which the whole criminal trialis based.

Even the provisions of article 5 paragraph1, letter $\mathrm{c}$ of the European Convention on Human Rights points out that a person can be deprived of liberty only when there are credible grounds to believe that leaving at large would represent a danger to society through committing other offences or fleeing of the culprit. Non-raising the cumulative criteria laid down in the national and European norms cannot be replaced with other considerations by the judge. We believe that the danger to the public order must be demonstrated and not based merely on allegation and contrary. In support of this presentation, there are also the provisions of article 5 of the ECHR, that the arrest of a person cannot be done at the expense of the principles of legal security and the protection against arbitrary, the judge must be vigilant and not allow the continuation of such measures when the factual data have changed during the process, but they do not justify, perfectly, the deprivation of liberty.

The need and proportionality of the measure to the gravity of the offenceshould be taken into account, otherwise in violation of the provisions of the article 6 of the ECHR and the Recommendation (80) 11 of the Committee of Ministers of the Council of Europe, because there are not serious reasons to believe that the defendant is a danger through retrieval from prosecution, by obstruction of Justice or committing other offences. In this respect, there is the ECHR practice, thus (by Scundeanu vs. Romania's decision of February 16, 2010, theECHRsanctioned the use of excessive danger to public order in abstract situations. The Court found that, in particular, there were sufficient reasons to believe that the defendant has committed a crime, but this is not enough to allow his arrest. The Court has recalled that the reference on the danger to the public order cannot be invoked from an abstract manner by the authorities; they must be based on evidence, not on the contrary and assumptions. The Court has recalled that, as decided in the Decision Letellier vs. France, taking into account the danger to the public order, may be made only in exceptional circumstances, where there is evidence to indicate the magnitude of the danger to the public order which would bereleasing the accused.The Court has recalled that, in The decision Calmanovici, the judicial authorities did not provide relevant and sufficient reasons to justify the need for maintaining the accused in provisional detention since they have not submitted concrete facts based on which the 
estimated risk of releasing the defendant, nor explained the impossibility of applying alternative measures of detention).

\section{The competent judicial authorities to} order the preventive measures and procedural laws which provide:

The preventive measure of detention can be disposed only at the stage of prosecution, both from the suspect, and against the defendant, and the competent bodies to provide this, are the Prosecutor, the criminal investigation bodies. Regarding the criminal investigation body, it may order forfeiture only in so far as the law shall recognize their own jurisdiction to conduct the criminal proceedings in question (under the supervision of the Prosecutor), not in cases where the criminal prosecution is carried out by the public prosecutor.[2, p. 423; 6]

With respect to the measure of arrest at home, as well as, the measure of preventive arrest, they are disposed by judge of rights and freedoms in criminal proceeding [7], in the preliminary chamber procedure by the judge of preliminary Chamber, and in the judgment by the Court.

Regarding the procedural act whereby the preventive measures are provided, the rules are governed by the provisions of the Criminal Procedure Code, as follows: in the case of detention, the prosecutor/the criminal research body provides by the motivated Ordinance (article 203 paragraph 4 of the Criminal Procedure Code), while the judge of freedoms and rights and the judge of preliminary Chamber and court shall provide by motivatedtermination with the difference that in the judgment, the basic Court may pronounce through the verdict [8], but also by a decision in the case of maintaining the measure of preventive arrest (according to article 423 paragraph 1 of the Criminal Procedure Code), and for the identity of reason, a Court of Appeal can decide on the continuation of thehome detention, considering the disposals of thearticle 208 paragraph 4 of the Criminal Procedure Code.
A particular situation about taking preventive measures is regulated by article 399 paragraph 10 of the Criminal Procedure Code, according to which "after the cancelation of the decision, towards appealingthe Court of Appeal, the Court may order, upon request or ex officio, taking, revoking, or replacing a preventive measure with respect to the defendant sentenced under the law", and have no importance in such cases if the case started the appeal, whether or not they declared the appeal, the condition is that the file should not have been filed to the Court for judicial review.[2, p. 424]

Resolving complaints concerning the preventive measures, in the competence of the judge for the rights and freedoms/ the preliminary Chamber or the Court, are made in the course of the criminal proceedings and the preliminary Chamber in the Council Chamber (article 5 paragraph 203 of the Criminal Procedure Code), during the unpublished session.[9]

Furthermore, as an exception to the general rule of pronouncement the decisions in the public session (article 405, paragraph 1 of the Criminal Procedure Code), the decisions in matters of preventive measures regarding criminal prosecution and preliminary Chamber stagesare pronounced in the Council Chamber.

In terms of judgment, the public or nonpubliccharacter of the Court session was not expressly stipulated in the case of preventive measures, and nor the waypublic or non-public of the session in which the judgment occurs.[10]

The public character of the court session is established expressly in the case in which the Court is obligated to verify, in the course of judgment, published during the session, the lawfulness and merits of the preventive measure, doing according to article 208 of the Criminal Procedure Code which means that this public data is justabout checking the ex officio by the Court to home arrest measures and preventive arrest. 
We conclude that the verification must be always donein terms of advertising, under the penalty of absolute nullity.

A difference between the procedure of the preliminary Chamber and the trial phase is related to the maximum period within which the Court is obliged to verify the grounds for what resulted in the maintenance of preventive arrest and home arrest, this term is a maximum of 60 days during the trial and 30 days in the preliminary Chamber procedure.

These terms are substantial;they are calculated in accordance with article 271 of the Criminal Procedure Code[11], their failure is punished with the termination of the measure in question, the sanction is ope legis since the fulfilment time.In matters of the preventive measures, the appeal may be exercised against the pronounced closings is the appeal, which can be declared within 48 hours from the present pronouncement or from the communication of the conclusion for those absent and it will be the judgment of a single judge of the rights and freedoms/ the preliminary chamber / the chair, even if judged at a higher court, except the High Court of Cassation and Justice.

With reference to the term of presenting the case from the first instance to the higher court, this is 48 hours, and the deadline for the resolution of appeal is five days (in the case of an appeal filed by the defendant), and as a general rule, regardless of the trial phase, in preventive measures, the contestationformulated by a Prosecutor against a closing that was willing to reject the proposal of preventive arrest, the revocation or replacement ofa preventive measure shall be settled before the expiry of the preventive measure laid out previously, if such initial term.[2, p. 426.]

As such, the holders of the right to exercise the remedy are the Prosecutor and defendant, the time limit of 48 hours being a procedural time limit under article 269 paragraph2 of the Criminal Procedure Code, its failure attracts the rejection as tardy summed up the appeal. [12]

The contestation can be driven either at the time of filing or at a later date, up to the time fixed for the attack way (according to article425parameter 1paragraph 3 of the Criminal Procedure Code), and can be withdrawn until the closure of the debate (in accordance with article 415 of the Criminal Procedure Code).

The solutions can be the acceptance of the appeal or its rejection as unacceptable, tardy or evidence less.

In terms of detention, against the Ordinance through which this measure was provided, the defendant/suspect detained has the right to make a complaint, the exercise of this right being made prior to the exhaustion of the term that has ordered the deprivation of liberty, the settlement of the complaint being performed by the Attorney who oversees criminal activity-when withholding is disposed of the criminal investigationbodies[13].

\section{Conclusions}

The exceptional character of preventive measures involving the deprivation of liberty is not only procedural but also by the provisions of the constitutional norms, [14] by the conventional rules [15], which require a number of guarantees with respect to liberty and security of the person. In the recent years, the ECHR jurisprudence, as well as the provisions of the European Convention occupied a very important role in terms of the solutions given by the Romanian magistrateson the preventive arrest and the home arrest.

Whereasthrough the preventive measures, the individual freedom is prejudiced, the European and national legislation have established a series of legal guarantees to prevent abuse and arbitrary in making and maintaining them. [2, p. 420.] 


\section{References}

[1] Article 9 of the Criminal Procedure Code; article 202 paragraph 1 of the Criminal Procedure Code.

[2] Nicolae Volonciu, Andreea Simona Uzlău şi alţii, Noul Cod de procedurăpenalăcomentat,Ed. Hamangiu, p.421, 2014; See also the article 11paragraph 2, article 147 paragraph 1 letter $b$, article 148 paragraph 1 let. b, article 150 paragraph 1 let. bof the Criminal Procedure Code.

[3] I.Neagu, M. Damaschin, Tratat de procedurăpenală. Parteagenerală.Înluminanoului Cod de procedurăpenală, Ed. UniversulJuridic, București, pp.628-629,2014.

[4] According to article. 202paragraphs 1-3 and article 223 of the Criminal Procedure Code „the measure of preventive arrest is necessary in order to ensure the proper course of the criminal process, in order to prevent the accused from avoiding prosecution or judgment, in order to prevent committing another offence ... the deprivation of liberty is necessary for the elimination of a threat to public order..."

[5] ECHR, judgment Fox, Campbell and Hartley vs. the United Kingdom, the decision of 30 august 1990.

[6] According to the article 324 paragraph 4 of the Criminal Procedure Code, the criminal investigation could not have withholding even by delegation of the Prosecutor: "Putting in motion the criminal action, taking or proposing restrictive measures of rights and freedoms, permitting evidence enforceability or layout of other procedural measures or acts may not form the delegation subject ..."

[7] There are exceptions, when the Prosecutor has the obligation and the right to establish closing of the preventive measures by Ordinance which has, in the course of criminal, classingtowards a defendant under such actions, regardless the provisions of the judicial body, pursuant to article 315 paragraph 4 of the Criminal procedure Code.

[8] See the provisions of article 399of the Criminal Procedure Code (the sentence which settled the criminal action).

[9] In accordance with the article 352 paragraph 1 of the Criminal Procedure Code "the meeting is public judgment, except as required by law. The meeting held in the Council Chamber is not public"...

[10] See article 352 paragraph 1 of the Criminal Procedure Code, and by way of exception to article 352 paragraphs 3 and 4 of the Criminal Procedure Code, or when the provisions of special laws expressly provide for this.

[11] In the calculation of the terms relating to the preventive measures or any other measures restrictive of rights, the time or the day which begins and ends go into its duration.

[12] Stelian Scăunaş, Răspunderea internaţională pentru violarea dreptului internaţional, Ed. All Beck, Bucureşti, p.83, 2002.

[13] Emilian Ciongaru, Custodial Sanctions Versus Community Sanctions, Monduzzi Editore, International Proceedings Division, Bologna, Italy,p.341, 2012.

[14] Costică Voicu, Florian Coman, Ştefania-Georgeta Ungureanu, Drept internaţional penal, Editura Pro Universitaria, 2007, p. 144.

[15] George T. Abed, Sanjeev Gupta, Governance, Corruption and Economic Performance, International Monetary Fund, WashingtonD.C., p.58-59,2003. 